\title{
THE USE OF MITIGATING DEVICES IN REQUESTS BY SERBIAN EFL LEARNERS
}

\author{
JOVANA DŽUNIĆ \\ BRANKICA ĆIRIĆ\& \\ SANJA JOVANOVIĆ 1 \\ University of Niš, Faculty of Philosophy, \\ Department of English Language and Literature, \\ Niš, Serbia
}

U ovom radu ispituju se načini na koje izvorni govornici srpskog koji uče engleski kao strani jezik koriste sredstva ublažavanja prilikom izražavanja molbi. Rad počinje definicijama i klasifikacijama pojmova koji se ispituju. Zatim, rad predstavlja ciljeve istraživanja koji uključuju upotrebu sredstava ublažavanja u molbama kod srpskih učenika engleskog kao stranog jezika kao i značaj učenja ovih pragmatičkih aspekata u školama. U radu se, dalje, navodi korišćeni metod i objašnjava se proces prikupljanja podataka. Na kraju rada se podaci dobijeni iz upitnika analiziraju i razmatraju se mogući rezultati. U zaključku se navode rezultati dobijeni istraživanjem i naglašava se potreba za učenjem ispitivanih pojmova.

Ključne reči: govorni činovi, molbe, sredstva ublažavanja, engleski kao strani jezik.

\section{INTRODUCTION}

\subsection{THEORETICAL BACKGROUND}

Requests are by definition the most face-threatening acts (Trosborg 1995: 187). She states that "a request is an illocutionary act whereby a speaker (requester) conveys to a hearer (requestee) that he/she wants the requestee to perform an act which is for the benefit of the speaker" and, sometimes, for the hearer. Therefore, requests are usually considered some kind of a threat or imposition to the hearer since "the speaker who makes a request attempts to exercise power or direct control over the

1 Kontakt podaci (Email): brankicaciric87@gmail.com; jovanadz@yahoo.com; sanjaj87@yahoo.com 
intentional behaviour of the hearer, and in doing so threatens the requestee's negative face" (Trosborg 1995: 188). There is a threat not only to the hearer's face but also to the speaker's as he/she may not comply with the request. Consequently, it is important to somehow lessen the impact of the request, which is achieved by the means of introducing additional peripheral elements to the core request i.e. mitigating devices or "expressions used to soften an imposition" (Yule 1996: 131). Carrying out a particular social function, mitigating devices are greatly considered a tactical means for reducing the strength of a speech act whose effects are undesirable to the hearer. Having such an essential function, these forms have been regarded as a fundamental part of the pragmatic competence for foreign language learners who usually face difficulties in acquiring the pragmatic principles of the target language (Usó-Juan and Martínez-Flor 2008).

\subsection{CLASSIFICATION OF MITIGATING DEVICES}

One of the possible classifications of mitigating devices is into internal and external. The difference between the two lies in the positioning of linguistic elements. Internal mitigating devices are found within the core request itself, whereas those which are external are placed in the immediate linguistic context surrounding the core request (Salazar Campillo 2007: 212). Moreover, these two types of mitigating devices can be further divided into subcategories for the purpose of providing a more detailed analysis. The classification and the examples presented in this pilot study are taken from the paper "Teaching learners to appropriately mitigate requests" (Usó-Juan and Martínez-Flor 2008: 349-357) since they appeared to be the most appropriate for this research.

Starting with the internal mitigating devices, three subtypes have been outlined:

1. openers - opening items and expressions that introduce the intended request. e.g.'Gentlemen, would you mind leaving us, please?'

2. softeners - items that soften the impositive force of the request, e.g. 'Listen, can I talk to you for a second?'; 'If you could possibly return this to Fred's for me, please.'

3. fillers - items that fill in gaps in the interaction, e.g. er; OK?; right?; excuse me; hello; you see.

Regarding the external mitigating devices, five subtypes have been identified:

1. preparators - devices that prepare the addressee for the subsequent request, e.g.'Colonel, I do have to ask you a couple of questions about September 6th.'

2. grounders - devices that give reasons that justify the request, e.g. 'Call my family, I'd like them to have dinner with me tonight.'

3. disarmers - devices that are employed to avoid the possibility of a refusal, e.g.'Colonel Jessep, if it's not too much trouble, I'd like a copy of the transfer order, Sir.'

4. expanders - devices related to repetition that are used to indicate tentativeness, e.g. 'Can you take him to the airport in the morning? ... Can you pick him up at 8.30?')

5. promise of a reward - devices that are used by the requester so that his/her request may be accomplished, e.g. '...she wants a bottle of wine ... I would promise to send you the money.' (Usó-Juan and Martínez-Flor 2008: 350-351). 
In addition, 'please' can also be considered another type of mitigating device, which is used to signal politeness, e.g. 'Would you hang up please and I'll call your machine?' (Usó-Juan and Martínez-Flor 2008: 351).

It can be stated that the learners of EFL should be aware of the existence of the listed mitigating devices so that they become more capable of appropriately using them in the given situations. Since many mitigating devices can be used in the same context, it is important that learners rely on interactional and contextual factors in choosing a particular pragmalinguistic form for performing a successful communication (Usó-Juan and Martínez-Flor 2008).

\section{RESEARCH OBJECTIVES}

A contrastive analysis of the use of specific politeness strategies in Serbian and English seems to demonstrate slight differences in the way native speakers of these two languages formulate certain types of speech acts - specifically, requests. Namely, it appears that, in formulating requests, Serbian native speakers most often tend to use positive and negative politeness strategies, or conventional indirectness, followed by a large number of hedges and grounders. However, speakers of Standard American English, for instance, demonstrate a higher use of internal modifiers, or fillers, especially hesitators, when compared to external modifiers. Considering the external mitigating devices, they tend to use please far more than other types. These observations were obtained from the comparison of the studies on the use of speech acts in Serbian, (Mišić-Ilić and Dimitrijević 2006, Mišić-Ilić 2008), as well as in English, where Standard American English is examined, (Martinez-Flor and Vilar Beltran, Al-Ali and Alawneh 2010).

Therefore, the main objectives of this study are:

1. To examine the use of mitigating devices in requests by Serbian students of EFL because: mitigating devices represent a very important feature of politeness present in requests produced by native speakers of English; this specific type of "communication facilitators" is most frequently used in everyday communication; the Serbian language generally exhibits a smaller degree of indirectness in formulating requests, and, therefore, apparently, a reduced usage of mitigating devices.

2. To emphasize the importance of the need of teaching pragmatic aspects in schools since it is essential that students master, among other linguistic phenomena, communicative competence of the given foreign language as well.

\section{RESEARCH METHOD}

The research assumes that the students are already familiar with the use of some of the mitigating strategies, primarily those involving modal verbs, the application of 
which is taught in grammar lessons only. It also assumes that the students will most probably opt for grammar constructions that are similar to those of their mother tongue, such as Could you please... to reflect the Serbian phrase Možete li, molim Vas...because they are used to using such phrases constantly in their mother tongue.

A group comprising a total of 47 students took part in the present study. These were 47 native speakers of Serbian - third grade students from the Humanities and Languages department in Pirot Grammar School, who study English as a foreign language five classes a week, their proficiency level being intermediate. The method used in this study is a discourse completion task. It should be noted that the expressions obtained from the responses in the questionnaire might be regarded as slightly unnatural since it is done in paper and pencil and not orally, which is considered a general flaw of this type of data elicitation method. Nevertheless, this type of data elicitation procedure is relatively easy to administer, especially among students who are used to completing tasks with pencil and paper since it does not put them in an unfamiliar situation.

\section{PROCEDURE}

The questionnaire comprising five different written scenarios was given in order to elicit the use of various mitigating devices in requests regarding specific situations appropriate to the participants' age and life experience. The five scenarios were chosen because they represented common, everyday situations, familiar to the participants; however, they differed in terms of relationships between the speaker and the hearer (social distance, relative status, degree of imposition, age), and in terms of request type (personal favor, requirement in a service encounter). The situations were created by the researches of this study according to the models provided by Takahashi in his study "The role of Input Enhancement in Developing Pragmatic Competence" (Kasper and Rose 2007: 298-299). However, the wording was slightly modified in order to shorten the amount of time the respondents needed to fill in the questionnaire so that the results are more valid. The situations were listed in a random order in terms of their level of formality. The questionnaire is given in the Appendix.

Two classes of students participated in the study. They were asked to read the five situations carefully and write the request they found appropriate for each case. It is important to accentuate that they had 20 minutes to complete the questionnaire so that more spontaneous reactions and responses were elicited. The explanation was given in advance without special emphasis on the use of particular mitigating devices.

\section{RESULTS AND DISCUSSION}

The main purpose of this pilot study was to analyze the use of mitigating devices in requests produced by a group of Serbian students who learn English as a foreign language. 
In the first situation, the speaker needs to avoid the imposition on the hearer because there is a great distance between the two. The hearer is a higher authority who is supposed to make an exception in this case only for the benefit of the speaker. There was obviously a tendency to use grounders predominantly. The subjects thought that this was the most effective strategy for achieving the goal because they felt an urge to justify the reason for making the request. The subjects mostly used phrases from the given text (I had a really bad cold; I was not able to come). Furthermore, the students opted out for softeners, such as Could you possibly...; Professor, can I talk to you for a moment, please?

The following situation posed a challenge to the students. It was an exception to the others since the speaker was not making a request to benefit him/herself but the hearer instead. Although this reverse situation is a polite offer on behalf of the speaker, it may, nevertheless, represent an imposition on the hearer as he/she may not need or want any help. Apparently, the most frequently used type of mitigating devices were fillers, specifically attention-getters, such as hey, and hi. Some of the examples where the students used them correctly were Hey, would you like me to help you?; Sorry, do you need some help?; Hi, dude, do you need some help?. As the situation was different, it posed a serious problem for the subjects, and some of them failed to recognize that it was they themselves who were supposed to offer help, and thus they were asking for help instead. For instance, they wrote Hey, could you help me move to the new apartment?

The third situation represents an interaction between a student and a professor who is at least ten years older than the student. The most frequent mitigating devices accompanying the request were fillers, i.e. attention getters - Excuse me, professor or Professor. They were followed by softeners such as If you could possibly lend me your dictionary, please?, and grounders such as: It is really necessary for me; I need it for my homework, and I left mine at home.

In situation number four, which represents a state of emergency in an everyday situation, it was noted that the greatest number of fillers was used. Some of the examples including cajolers were You see, I really need to make a call.; You know, I need to ask you something. There were also a few instances of hesitators like Hmmm, can I, please, use your phone? or Mmmm, would you lend me your phone, please? As expected, attention-getters were quite frequent in this situation as well: Sorry, I need to make a call. Can you give me your cell phone?; Hello, my dear, I have a problem ...; Apart from them, students also used an equal number of softeners and grounders, often in the same sentence, for example: Could you maybe give me your phone just to tell my mom not to worry?

Contrary to the previous situation, the last one posed the majority of students with an unfamiliar real-life situation since it involved meeting with a loan officer in a bank. The least number of fillers was used here; however, most students opted for various types of grounders since they felt they needed an extensive justification for their requests. Thus, they used expressions like Two weeks is too long a period for me to wait; I have to pay my tuition as soon as possible.; It's urgent. 
The following table sums up the results expressed in numbers:

\begin{tabular}{|c|c|c|c|c|c|c|c|c|}
\hline \multirow[b]{2}{*}{ 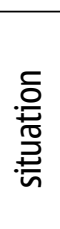 } & \multicolumn{3}{|c|}{ INTERNAL } & \multicolumn{5}{|c|}{ EXTERNAL } \\
\hline & 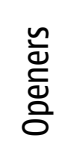 & 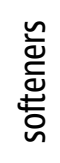 & $\frac{\stackrel{\check{\varrho}}{E}}{\underline{E}}$ & 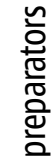 & $\begin{array}{l}\frac{n}{\frac{0}{0}} \\
\frac{0}{5} \\
\text { 흠 }\end{array}$ & & 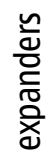 & 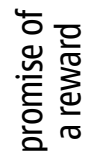 \\
\hline 1 & 19 & 25 & 27 & 11 & 29 & 0 & 0 & 4 \\
\hline 2 & 1 & 2 & 22 & 6 & 18 & 4 & 0 & 0 \\
\hline 3 & 8 & 18 & 30 & 8 & 17 & 3 & 0 & 0 \\
\hline 4 & 0 & 24 & 40 & 7 & 24 & 4 & 0 & 1 \\
\hline 5 & 7 & 24 & 15 & 20 & 35 & 3 & 0 & 0 \\
\hline 宽 & 35 & 93 & 134 & 52 & 123 & 14 & 0 & 5 \\
\hline
\end{tabular}

To start with, it is clear that more than one type of mitigating devices was used in the response to one situation. As it can be observed from the table, except for expanders, all other mitigating devices were used. The results indicate that the highest amount of devices used were fillers, followed by grounders, then softeners and openers, while disarmers and promises of a reward show the least frequency of use.

The reason for not using expanders in any of the given situations may be that the subjects did not find it natural to use them, or perhaps are not familiar with their use simply because expanders are not frequent in their native language.

Fillers are used most in almostall of the situations, especially attention-getters such as excuse me and hello as they are a logical way of starting a conversation, regardless of the relative distance, power, and the degree of imposition on the hearer. Appealers such as $O k$ and right were also frequently used, primarily in the fourth situation since they indicate friendliness and positive politeness strategy.

Although openers have a similar function to fillers as conversation-starters, the results show a lesser degree of usage. The reason may be that in Serbian, speakers would rarely address hearers by sir or madam, for example, as they imply a much greater formality.

As far as preparators are concerned, the results show what could be taken as a general and logical conclusion: their use is more frequent when the degree of imposition on the hearer is greater. Therefore, more preparators will be used when the request requires a greater degree of politeness. For example, the fifth situation involves the greatest degree of imposition on the hearer, and, that is why the obtained requests included preparatory phrases such as I would like to ask you something.

Grounders are most common in the elicited answers. Apparently, while the students do not fail to apply various types of mitigating devices appropriately, what can be clearly stated is that they in most cases opt for grounders. This is probably due to the fact that this form of request is mostly used in Serbian, which is the general observation of the researchers, Serbian being their mother tongue. Thus, this obviously represents 
a case of language transfer from $L 1$ to $L 2$. The subjects clearly felt the use of grounders as most natural, as in this way they let the addressee know the purpose of the request and might reduce the threat to the hearer's face, and in this way reduce the possibility of rejection on the part of the hearer.

Generally, the results also support the idea that the students were aware of the level of formality and they varied the use of mitigating devices accordingly. Namely, they made more formal requests when they were addressing someone of a higher social status, and, they made less formal requests in the situations where they were interacting with their friends. Moreover, as it was expected, they used more than one mitigating device in the same situations. Finally, the use of please was very frequent among the students, probably because it is an explicit and transparent marker of politeness commonly used in both languages.

\section{CONCLUSION}

Our pilot study aimed at examining the use of mitigating devices by Serbian learners of English as a foreign language while completing a discourse completion task. The obtained results indicate, as it was assumed, that the students use some of the mitigating devices, particularly those involving modal verbs, such as Could you please..., Would you be so kind as to..., May I...

The most important finding that stems from this pilot study is the slight difference in the choice of particular mitigating devices found in the requests produced by native and non-native speakers of English. Namely, the study previously mentioned in the paper that investigates the use of mitigating devices by the native speakers of American English (Martinez-Flor and Vilar Beltran) has shown a discrepancy with the results obtained in the examination of the subjects of this study i.e. native speakers of Serbian learning English. First, while both groups tend to use fillers most, it appears that with the native speakers of American English, softeners make up the second largest group by the frequency of their use, while with the examinees it is the grounders that make up the second largest group. Furthermore, unlike the native speakers of American English, Serbian EFL learners appear to opt for preparators more than disarmers, which could perhaps also be contributed to by the transfer from their mother tongue. Nevertheless, it must be pointed out that the use of preparators varies generally depending on the degree of imposition on the part of the speaker. The lack of use of expanders could be yet another example of the influence of cultural factors, given that their use is infrequent in Serbian, as observed by the researchers, whose mother tongue is Serbian.

Taking everything into consideration, the implications of this study must be pointed out. The study could raise awareness of the importance of teaching the proper use of mitigating devices in EFL classrooms. As the results demonstrate, the examinees do not seem to use mitigating devices and the request speech act as naturally as possible in the target language, which is another conclusion from the comparison with the native speakers of English. As linguistic competence requires also pragmatic competence, it is essential for the students to be instructed in pragmatic aspects in order to achieve cooperation in a conversation (Mišić-Ilić and Dimitrijević 2006). If formal instruction 
of the communicative competence of the target language is not carried out, several problems can occur. For instance, insufficient communicative competence may result in an inappropriate message exchange between the interlocutors, either in comprehension or production. "Worse yet is the possibility of a total communication breakdown and the stereotypical labeling of second language users as people who are insensitive, rude, or inept" (Eslami-Rasekh 2005). When a request speech act is in question, the stress on the appropriate use of mitigating devices is more than necessary, since requests are the most face threatening to the hearer, as already mentioned. The choice of one mitigating device over another could be crucial in particular situations, for example, the misuse of the promise of a reward in a situation in which there is a greater social distance and the degree of power between the requester and the requestee, which could be taken as a grave insult.

\section{REFERENCES}

Al-Ali, M. N. and R. Alawneh. 2010. Linguistic Mitigating Devices in American and Jordanian Students' Requests. [Internet]. Available at: http://related.springerprotocols.com/ Ip/de-gruyter/linguistic-mitigating-devices-in-american-and-jordanian-students9IVIIzXR8f [04.05.2011].

Eslami-Rasekh, Z. 2005. Raising the pragmatic awareness of language learners. ELT Journal 59(3), 199-208.

Martinez-Flor A. and E. Vilar Beltran. Analysing English Native Speakers' Use of Request Modification Devices During a Role-Play Activity. Available at: http://www.um.es/ lacell/aesla/contenido/pdf/1/vilar.pdf [04.05.2011].

Mišić Ilić, B. and M. Dimitrijević. 2006. Lice u ogledalu pragmatike: kako jezikom sačuvati obraz. U B. Čubrović i M. Daničič (ur.) Lice u jeziku, književnosti i kulturi. Beograd: Philologia, 129-145.

Mišić Ilić, B. 2008. Jezički i kulturni aspekti govornog čina zabranjivanja iz ugla kontrastivne pragmatike. Niš: Filozofski fakultet.

Rose, K. R.. and G. Kasper. 2007. Pragmatics in language teaching. Cambridge: CUP.

Salazar Campillo, P. 2007. Examining Mitigation in Requests: A Focus on Transcripts in ELT Coursebooks. In E. A. Soler and M. P. Safont Jordà (eds.) Intercultural Language Use and Language Learning. Dordrecht: Springer.

Trosborg, A. 1995. Interlanguage pragmatics: requests, complaints, and apologies. Berlin: Mouton de Gruyter.

Usó-Juan E. and A. Martínez-Flor. 2008. Teaching learners to appropriately mitigate requests. ELT Journal 62(4), 349-357.

Yule, G. 1996. Pragmatics. 0xford: OUP. 


\section{SUMMARY}

\section{THE USE OF MITIGATING DEVICES IN REQUESTS BY SERBIAN EFL LEARNERS}

The paper presents the examination of the ways Serbian EFL students use mitigating devices in realizing the speech act of requesting. Beginning with definitions and classifications of the main concepts, the paper presents the two main objectives of the study: the use of mitigating devices in requests by Serbian learners of EFL, and, the emphasis on the importance of teaching pragmatic aspects in schools. The method used in the research is presented, and the process of data collection explained. The data obtained from the discourse completion task are analyzed, and the possible results discussed. Finally, the research results are stated, and the attention is drawn to the importance of teaching the use of mitigating devices and to the promotion of students' pragmatic development in EFL classroom settings.

KEYWORDS: speech acts, requests, mitigating devices, EFL.

\section{APPENDIX}

Imagine you found yourself in the situations given below. Write down the request you would formulate in each of the situations when you ask someone for a specific thing.

1) Since you had a bad cold, you could not take a final exam for the English grammar course. But you want to take a makeup exam for the course because you have an excuse: you could not take it due to your bad health, so you have decided to ask Professor E. (in charge of the course) to give you a makeup exam for the course.

2) You are asking a close friend to help him/her move to a new apartment.

3) You want to borrow a dictionary from a professor who is at least ten years older than you.

4) You are asking a fellow student to make a call from his/her cell phone.

5) You are applying for a student's loan at a bank and are meeting with the loan officer. The loan officer is the only person who reviews the applications at this bank. He/she tells you that there are many other applicants and that it will take two weeks to review your application. However, you want the loan to be processed in order to pay your tuition on time.

(Original scientific paper received 30.01.2012; revised 31.10.2012; accepted 30.11.2012) 